\title{
Herbivory by reef fishes and the production of dimethylsulfide and acrylic acid
}

\author{
J. W. H. Dacey ${ }^{1}$, G. M. King ${ }^{2}$, P. S. Lobel ${ }^{1}$ \\ ${ }^{1}$ Biology Department, Woods Hole Oceanographic Institution, Woods Hole, Massachusetts 02543, USA \\ ${ }^{2}$ I. C. Darling Center, University of Maine, Walpole, Maine 04573, USA
}

\begin{abstract}
The content of dimethylsulfoniopropionate (DMSP) in selected marine reef macrophytes was examined and related to levels of DMSP and one of its decomposition products, dimethylsulfide (DMS), in guts of herbivorous fish. Concentrations of short-chain fatty acids and acrylic acid (ACR), another decomposition product of DMSP, were also measured in gut contents. The fatty acid data provide evidence for bacterial fermentation within fish intestines. Unlike previous observations of gut microflora, the concentrations of ACR in these guts did not support a role for ACR as an inhibitor of the gut microflora. DMSP also appears to concentrate in the tissues of certain fish, but not in others. These results illustrate the complex trophic interactions which determine the dynamics of DMSP in the marine food web.
\end{abstract}

KEY WORDS: Dimethylsulfide - Dimethylsulfoniopropionate - Acrylic acid - Marine algae - Seagrass . Scaridae Pomocentridae $\cdot$ Acanthuridae - Gut microflora - Caribbean reefs

\section{INTRODUCTION}

The geochemical and geophysical importance of atmospheric dimethylsulfide (DMS) has brought a wide spectrum of biological processes into focus because of their roles in DMS formation. Marine DMS constitutes perhaps as much as one quarter of the gaseous emission of sulfur (including anthropogenic emissions) entering the atmosphere (Andreae 1990). There is increasing evidence that the atmospheric oxidation products of DMS, particularly sulfate and methanesulfonic acid, are important in the formation of aerosols in the lower atmosphere. It has been proposed that these aerosols are important as cloud nucleation sites (Shaw 1983, Charlson et al. 1987). Formation of these aerosols may have consequences for the earth's albedo, and hence its heat balance. The importance of this emission in terms of global atmospheric budgets, and its potential importance in aerosol formation, has heightened interest in the biogeochemistry of DMS in the surface ocean.

In marine systems dimethylsulfide is primarily the decomposition product of a compound, dimethylsulfoniopropionate (DMSP), produced by marine plants. Since Challenger \& Simpson (1948) first discovered
DMSP in the filamentous red alga Polysiphonia fastigiata, it has been reported for a large number of marine species. Subsequent study has shown that DMSP is present in high concentrations in dozens of marine macroalgae (White 1982, Reed 1983) and phytoplankton (Keller et al. 1989). In contrast, the presence of high concentrations of DMSP in higher plants is limited to a few species (Spartina alterniflora: Dacey et al. 1987; S. anglica: Larher et al. 1977, van Diggelen et al. 1986; $S$. foliosa: Dacey unpubl.; Wedelia biflora: Pitman \& Storey unpubl. data cited in Wyn Jones \& Storey 1981). Though the physiological role of DMSP remains uncertain, there is strong evidence in support of an osmotic function. In Ulva lactuca, DMSP levels adjust according to changes in salinity (Dickson et al. 1980, 1982). The concentrations of DMSP in certain phytoplankton are also consistent with a role in osmotic balance (Vairavamurthy et al. 1985); however the dynamics of the compound are very poorly known.

One important aspect of the biogeochemistry of DMSP is the fact that the major mechanisms of DMSP degradation do not appear to be directly linked to plant physiology. Most marine DMS appears to arise from the decomposition of DMSP after release from phytoplankton; one potentially key regulatory step in 
this process is grazing of phytoplankton by zooplankton (Dacey \& Wakeham 1986, Belviso et al. 1990, Leck et al. 1990). There is increasing evidence that the DMSP decomposition is actually mediated by 2 processes: one in the digestive turnover of DMSP in the zooplankton gut, the other being a microbial decomposition of DMSP released subsequent to the act of grazing (Wakeham \& Dacey 1989, Kiene 1990). Algae are known to contain enzymes which degrade DMSP (Cantoni \& Anderson 1956, Kadota \& Ishida 1968), and perhaps the rupturing of cells may facilitate this conversion during mastication and digestion. Free DMSP may also be decomposed to DMS by intact phytoplankton (Stefels et al. 1993).

The importance of food-chain processes in the formation of DMS raises questions about the potential role of herbivorous fish as agents of DMSP decomposition. Another important facet of the problem involves the incorporation of DMSP into fish tissue. Much of the early interest in DMSP arose because it was found to be responsible for certain problems in fish flavor. DMSP was found to accumulate in fish preying on certain food species, and in processing of the fish, the decomposition product, DMS, presented a problem in fish flavor. The 'Blackberry' problem off the Labrador coast and a similar disorder, termed 'gunpowder', which occurs off Iceland, are both attributable to the presence of a DMSP-containing pteropod, Limacina helicina, in fish guts (Sipos \& Ackman 1964, Ackman et al. 1966, 1967). Motohiro (1962) showed that the Pacific chum salmon Oncorhynchus keta contained significant levels of DMSP which were decomposed to DMS during the canning process, giving rise to a 'petroleumlike' odor. This condition also was associated with feeding on L. helicina. The fact that DMSP accumulated particularly in the muscle of chum salmon, but not red salmon, was related to transmethylation activity in the fish livers. DMSP entering the blood was carried to the liver of fish; incomplete transmethylation in chum salmon liver allowed significant quantities to accumulate in muscle, where no transmethylation activity was measurable. Other studies have demonstrated presence of DMSP in fish (Iida et al. 1986, Shiomi et al. 1982) and shellfish (Iida \& Tokunaga 1986).

The major process by which DMSP is decomposed to DMS results in the concomitant formation of acrylic acid (ACR) (Challenger 1959). Sieburth $(1960,1961)$ found that ACR levels in guts of penguins reached concentrations sufficient to arrest the growth of the gut microflora. Sieburth observed that penguins ingested krill which fed on the DMSP-containing phytoplanton Phaeocystis pouchetii, and concluded that the aerobic microflora of the guts of these penguins were much reduced due to the 'bioconcentration of DMSP' that led to elevated levels of ACR. On the other hand, herbivorous marine turtles and some fishes are known to have a gut in which an active microbial fermentation occurs (Bjorndal 1980, Rimmer \& Wiebe 1987); in fact, the largest known prokaryote has been isolated from the intestine of a herbivorous acanthurid (Clements \& Bullivant 1991).

Ingestion of DMSP-bearing food can have a broad spectrum of consequences. Some DMSP is undoubtedly decomposed to DMS and ACR. The ACR may have bacteriostatic effects within the gut. Some of the DMSP may also be retained in the animal tissue, potentially leading to accumulations which might impact palatability. This study investigated these aspects of DMSP ingestion by herbivorous reef fishes.

\section{MATERIALS AND METHODS}

Samples were collected by SCUBA at the West Indies Laboratory, Fairleigh Dickinson University, St. Croix, U.S. Virgin Islands. We collected samples of marine macrophytes (algae and vascular plants) in the lagoon and reef area in the vicinity of the laboratory. Fish specimens were collected alive by netting and rapidly transferred to the laboratory. Fish were then anesthetized, killed and dissected.

Samples were assayed for DMSP and water content in the laboratory. Analyses for DMS and DMSP were conducted using an $\mathrm{HNU}$ photoionization detector. A $185 \mathrm{~cm}$ length of Chromosil 330 (Supelco, Inc., Bellefonte, PA, USA) in FEP tubing was used for chromatographic separation. DMSP was quantified by digesting material, plant or animal, in $2 \mathrm{~N} \mathrm{KOH}$. After addition of base, samples were allowed to sit for $24 \mathrm{~h}$ at room temperature. DMSP is measured as DMS released on treatment with base. The base-catalyzed production of DMS is quantitative for DMSP, which decomposes stoichiometrically to DMS and ACR by an elimination reaction. The kinetics of this reaction are well defined (Dacey \& Blough 1987). It is also possible, though unlikely, that other compounds may be present to release DMS since there appear to be very few other naturally occurring compounds which will generate DMS on treatment with base. The most common sulfonium compound which also yields DMS on treatment with base is S-methylmethionine (SMM), but its concentrations in living tissue are unlikely to reach mmol $1^{-1}$ levels and the kinetics of the elimination for SMM are much slower, requiring heating to achieve comparable reaction rates. Another compound which has been measured in low concentrations in a marsh species is dimethylsulfoniopentanoate, but there is no evidence of its significance among plant species (Larher \& Hamelin 1979). 
Base digestions of gut contents are treated as DMSP+DMS, since no partitioning between the pools was possible. Standards were prepared from a DMS solution $\left(14 \mathrm{mmol}^{-1}\right)$ in acidic $(1 \% \mathrm{HCl})$ methanol prepared in Woods Hole and transported to St. Croix. DMSP+DMS was quantified by analysis of DMS concentrations in headspace over base-treated samples. Experience has shown that these assays are accurate to within $<15 \%$.

Concentrations of short-chain fatty acids (SCFA) and ACR were determined after extracting weighed fresh gut contents with methanol. The gut contents were obtained from tissue samples collected as above. The foregut and hindgut regions were defined operationally as the first and last thirds of the intestine, respectively. No physical differentiation was otherwise obvious. The gut contents and methanolic extract were stored in Balch tubes with butyl stoppers and aluminum crimp seals and transported to the University of Maine for analysis. Undiluted extract (1 to $2 \mu \mathrm{l}$ ) was injected into a $2 \mathrm{~mm}$ (ID) $\times 2 \mathrm{~m}$ glass column contain SP-1200 (Supelco). SCFA and ACR were detected by a flame ionization detector.

\section{RESULTS}

DMSP contents of selected plant species possibly present in the diet of herbivorous reef fishes were variable (Table 1), but generally lower than concentrations found in certain classes of phytoplankton, such as coccolithophorids and dinoflagellates (Keller et al. 1989). These data represent the first measurements of DMSP for many of these plant genera. Consistent with previous surveys of macroalgae, the data showed variability within and between taxa, with phaeophytes tending to have lower concentrations. In some instances, epiphytes contributed significantly to the DMSP content observed for some plant species (Table 1). For example, it appeared that the bulk of DMSP associated with the seagrass Thalassia testudinum was attributable to epiphytes. Consistent with the observations that DMSP is concentrated in epiphytized lamina, non-epiphytized $T$. testudinum contained no detectable ACR, but epiphytized plants contained $37.5 \mathrm{nmol} \mathrm{g}^{-1}$ fresh wt.

DMSP concentrations in muscle tissue varied among a variety of scarids, pomacentrids, and acanthurids (Table 2). The feeding habits and food selectivity of the fishes listed in Table 2 are well known (Randall 1967, Emery 1973, Clavijo 1974, Lobel 1980, Lobel \& Ogden 1981, Targett et al. 1986, Duarte \& Acero 1988). Consistent with the known preference of Sparisoma radians (Scaridae) for the epiphytized Thalassia testudinum leaves, DMSP was much higher in tissue of
Table 1. Survey of DMSP in plants at St. Croix

\begin{tabular}{|c|c|}
\hline Plant type & $\begin{array}{c}\text { DMSP } \\
\left(\mu \mathrm{mol} \mathrm{g}{ }^{-1} \text { fresh } w t\right)\end{array}$ \\
\hline \multicolumn{2}{|l|}{ Spermatophyta (flowering plants) } \\
\hline Halodule wrightii & 3.3 \\
\hline Syringodium filiforme & 0.10 \\
\hline \multicolumn{2}{|l|}{ Thalassia testudinum } \\
\hline Non-epiphytized leaf & $0.18,0.21$ \\
\hline Epiphtytized leaf & $0.64,1.4$ \\
\hline Epiphytized, moribund leaf & $2.9,4.0$ \\
\hline Rhizome & 0.01 \\
\hline \multicolumn{2}{|l|}{ Chlorophyta (green algae) } \\
\hline Avrainvillea geppi & 0.33 \\
\hline Caulerpa cupressoides & 0.07 \\
\hline Caulerpa sertularoides & 0.04 \\
\hline Cladophora sp. & 0.94 \\
\hline Dictyospheria cavernosa & 1.4 \\
\hline Halimeda incrassata & 0.33 \\
\hline Penicillus pyriformis & 0.16 \\
\hline Pocokiella variegata & 0.08 \\
\hline \multicolumn{2}{|l|}{ Rhodophyta (red algae) } \\
\hline Galaxura subverticulata & 0.60 \\
\hline Hypnea cervicornis & 0.40 \\
\hline Hypnea spinella & 0.15 \\
\hline liagora valida & 0.68 \\
\hline Pterocladia americana & 0.13 \\
\hline \multicolumn{2}{|l|}{ Phaeophyta (brown algae) } \\
\hline Dictyota sp. & 0.15 \\
\hline Padina sp. & 0.32 \\
\hline Turbinaria turbinata & 0.05 \\
\hline \multicolumn{2}{|l|}{ Miscellaneous } \\
\hline Brown filamentous turf & 1.4 \\
\hline Sand & 0.02 \\
\hline
\end{tabular}

this species than in other species. DMSP+DMS in gut contents was also almost an order of magnitude higher in the gut contents of this species than its congener, $S$. viride (Fig. 1). The acanthurids Acanthurus bahianus, $A$. chirurgus, and $A$. coeruleus, and the pomacentrids

Table 2. Survey of DMSP in muscle tissue of various reef fishes

\begin{tabular}{|c|c|}
\hline Fish species & $\begin{array}{c}\text { DMSP content } \\
\left(\mu \mathrm{mol} \mathrm{g}^{-1} \text { fresh wt }\right)\end{array}$ \\
\hline \multicolumn{2}{|l|}{ Scaridae (parrotfish) } \\
\hline Sparisoma radians & 0.32 \\
\hline Sparisoma veride & 0.001 \\
\hline \multicolumn{2}{|l|}{ Pomacentridae (damselfish) } \\
\hline Stegastes planifrons & $0.004,0.002$ \\
\hline Stegastes dorsopunicans & 0.008 \\
\hline \multicolumn{2}{|l|}{ Acanthuridae (surgeonfish) } \\
\hline Acanthurus coeruleus & $0.048,0.003$ \\
\hline Acanthurus bahianus & 0.006 \\
\hline Acanthurus chirurgus & 0.004 \\
\hline
\end{tabular}




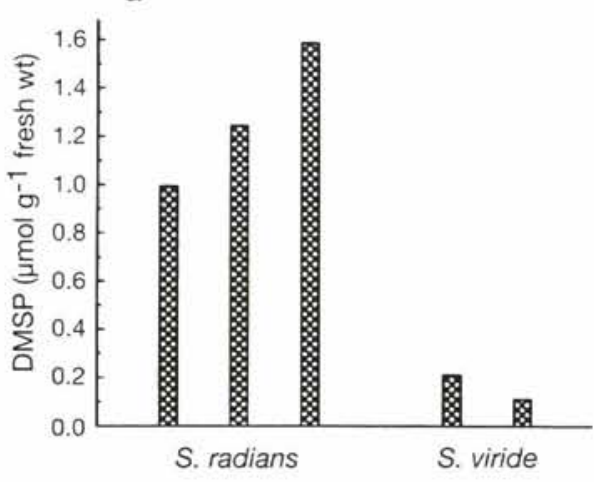

b

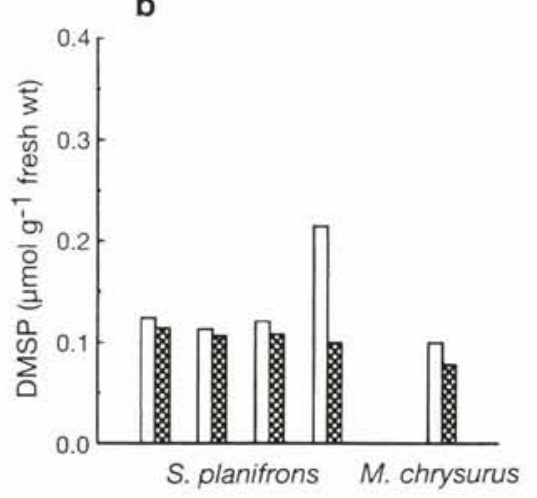

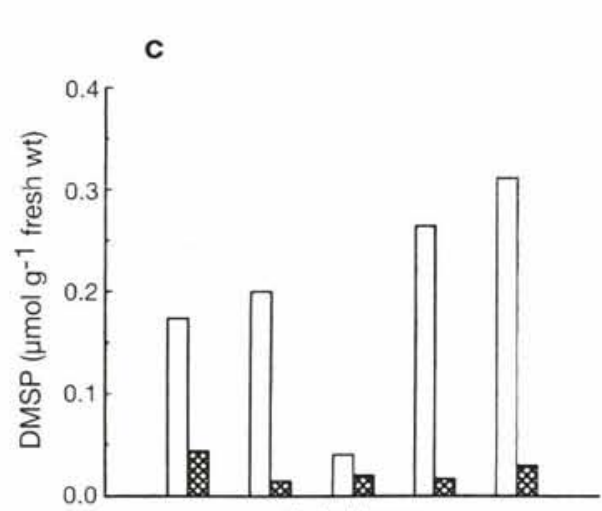

A. bahianus

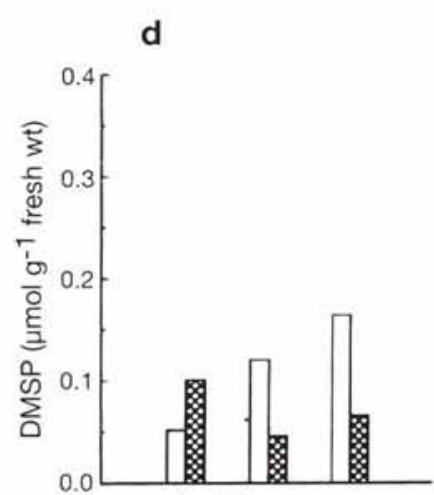

A. chirurgus

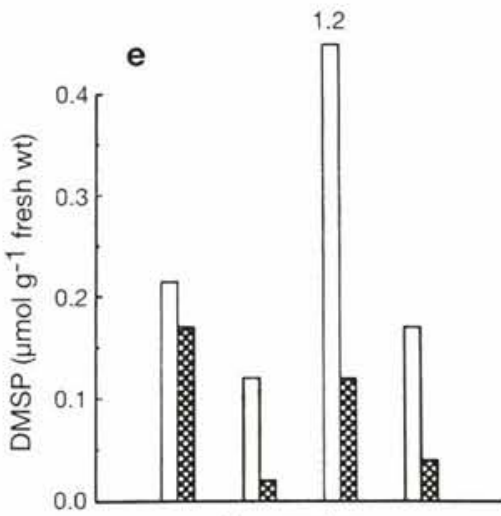

A. coeruleus

Fig. 1. DMSP+DMS in gut contents of various herbivorous reef fishes. Each bar or pair of bars represents data from an individual fish. Note that the ordinate axis is expanded in (a) for Sparisoma spp. (a) Sparisoma radians and S. viride. (b) Stegastes planifrons and Microspathodon chrysurus. (c, d, e) Three species of Acanthurus: A. bahianus, A. chirurgus, and A. coeruleus

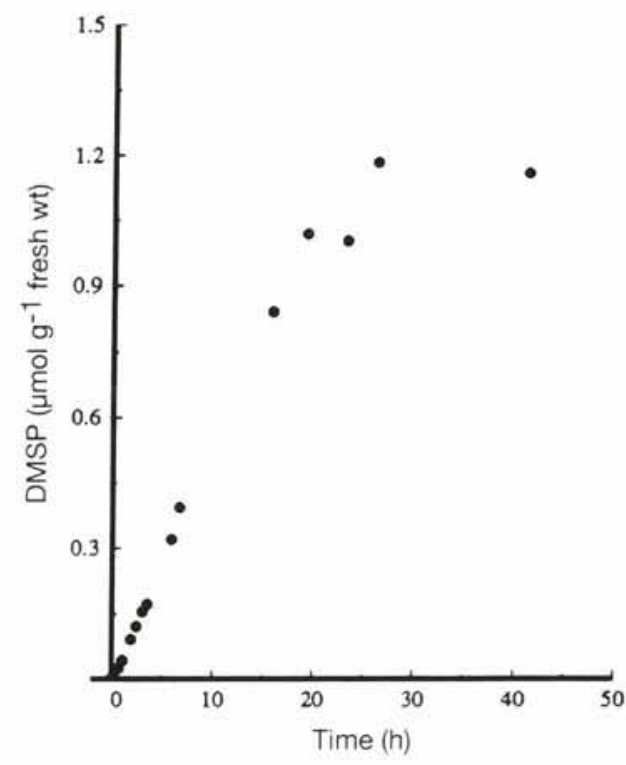

Fig, 2. Sparisoma radians. Timecourse of DMS formation in gut contents
Stegastes planifrons and Microspathadon chrysurus had comparable DMSP contents (Fig. 1). In most cases, DMSP concentrations were higher in stomachs than in hind-guts, except in the case of one sample of $A$. chirurgus.

The net rate of DMS production from isolated gut contents of Sparisoma radians was highest (and constant) during the first $6 \mathrm{~h}$, and stopped after $24 \mathrm{~h}$ (Fig. 2). A $0.96 \mathrm{~g}$ sample of gut contents was used in a $28 \mathrm{ml}$ incubation tube, and with frequent swirling, delays in headspace equilibration were not likely a significant component of the observed kinetics. We also observed DMS production from feces of $S$. radians, but did not quantify its rate.

ACR was present among the different fishes and tissues sampled in concentrations ranging between 10 and $300 \mathrm{nmol} \mathrm{g}^{-1}$ fresh wt (Fig. 3). The concentrations of ACR tended to decrease consistently from the stomach to the hindgut in all of the fish species sampled (Fig. 3), with the exception of a single sample of Epinephelus morio (Serranidae), in which no ACR was detectable in the stomach, but which contained modest 


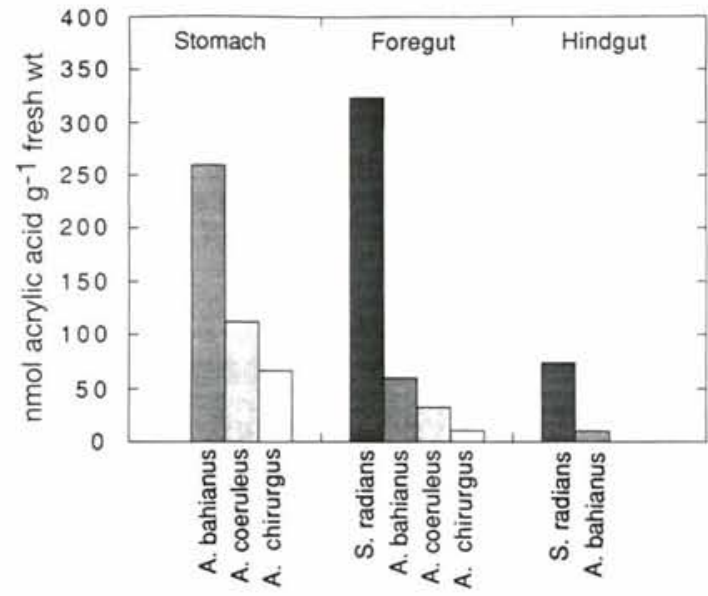

Fig. 3. Acanthurus spp., Sparisoma radians. Acrylic acid concentrations in gut contents of reef fish

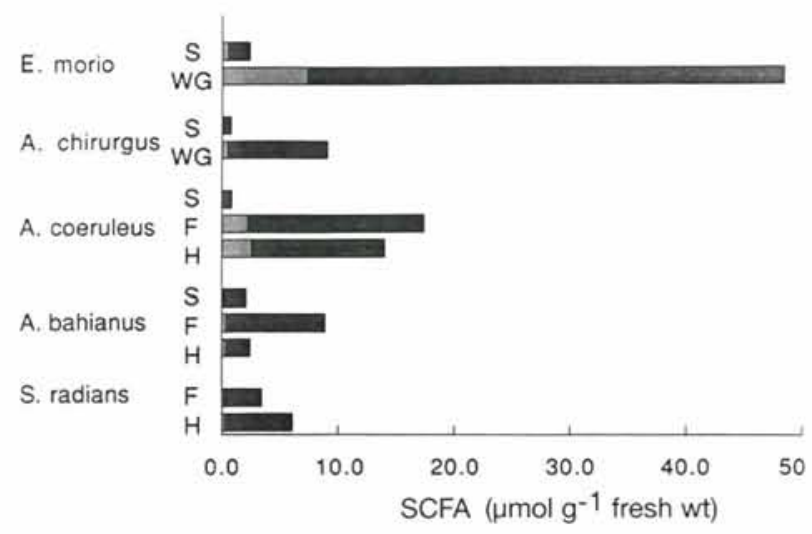

Fig. 4. Epinephelus morio, Acanthurus spp., Sparisoma radians. Concentrations of short-chain fatty acids (SCFA) in gut contents. S: stomach; WG: whole gut; $\mathrm{F}$ : foregut; $\mathrm{H}$ : hindgut. Dark stippling: acetate; light stippling: sum of other SCFA

concentrations in the gut (about $74 \mathrm{nmol} \mathrm{g}^{-1}$ fresh wt). ACR concentrations were also lower in the guts of Sparisoma radians which were fed non-epiphytized Thalassia testudinum, compared with $S$. radians fed epiphytized $T$. testudinum (61.6 and $13.2 \mathrm{nmol} \mathrm{g}^{-1}$ fresh wt in whole guts respectively).

Each of the various gut samples contained a variety of SCFA, with acetate predominating in all cases (Fig. 4). SCFA concentrations were variable among fishes and gut contents ranging from $<1$ up to $41 \mu \mathrm{mol}$ $\mathrm{g}^{-1}$ fresh wt in the stomach of Acanthurus chirurgus and gut of Epinephelus morio, respectively. Concentrations of other SCFA (e.g. propionate, butyrate, isovalerate) were usually 10 -fold lower. The most diverse array of SCFA was found in the guts of A. coeruleus and E. morio, with acetate, propionate, butyrate, iso- butyrate and iso-valerate all present. Fewer SCFA were found in the other species. In contrast to patterns for ACR and DMSP, SCFA concentrations increased significantly from the stomach to the gut; this was especially pronounced in A. coeruleus, A. chirurgus and E. morio.

\section{DISCUSSION}

Trophic processes are important in the dynamics of DMSP and DMS in marine systems. In reef communities, some plant species contain fairly high levels of DMSP. The 2 preferred food species for the scarid Sparisoma radians are epiphytized macrophytes Thalassia testudinum and Halodule wrightii (Lobel \& Ogden 1981), which had the highest DMSP contents in this study. T. testudinum represents about $70 \%$ of the diet of this fish. The older, more epiphytized lamina contain the higher levels of DMSP (Table 1), which suggests that the epiphytes contain the abundance of DMSP, not the T. testudinum itself. As partial confirmation of this conclusion, root concentrations in $T$. testudinum are very low, but that does not preclude DMSP accumulation by leaves. For example, the marsh grass Spartina alterniflora accumulates $>50$ $\mu \mathrm{mol} \mathrm{g}{ }^{-1}$ fresh wt in leaves while root concentrations are $<10 \mu \mathrm{mol} \mathrm{g}^{-1}$ fresh wt (Dacey et al. 1987). Epiphytes are undoubtedly the source of ACR in the plant tissue as well, since little DMSP and no ACR were detected on non-epiphytized leaves.

ACR in the epiphytized leaves accounts for only part of the concentrations observed in Sparisoma radians guts during the feeding experiment, and very little of that found in fish collected from the field. Hydrolysis of ingested DMSP is the likely source of the bulk of gut ACR: the resulting formation of DMS was observed during the in vitro incubation of gut contents. The distribution of ACR along with the distribution of DMSP also demonstrate that the stomach is the major locus of DMSP hydrolysis. Hydrolysis might also occur in the gut, but this activity would be limited by the residual concentrations in material transported from the stomach. The relationship between ACR and DMSP+DMS (Fig. 5) suggests that ACR is higher in fish with higher DMSP in their diet, and that ACR derives primarily from DMSP. The fact that ACR is generally about $50 \%$ of the DMSP concentrations suggests that DMSP is approximately equal to DMS (assuming a 1:1 stoichiometry for DMS and ACR) and that some of the ingested DMSP may be excreted. This conclusion is consistent with observations that fish feces emit DMS, probably from residual, undegraded DMSP. Pool sizes of DMS in the guts are required for further corroboration of this point. 


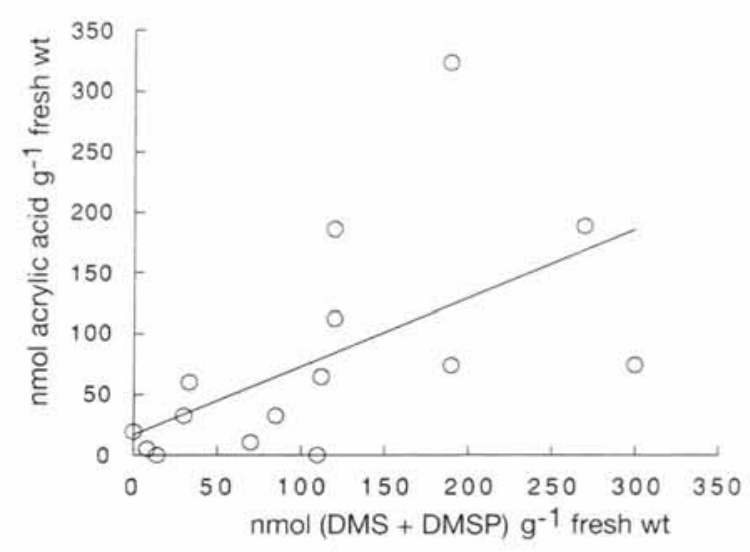

Fig. 5. Relationship between ACR and DMSP+DMS in gut contents of several fish species $\left(r^{2}=0.33, p=0.026\right)$

The general pattern of decrease in both DMSP and ACR concentrations from stomach to hindgut indicate that these compounds are readily utilized, either by absorption across the gut wall, bacterial degradation, or both. The loss of ACR is not surprising since its inhibitory effects are usually expressed at much higher concentrations than observed in this study (Sieburth 1961). Thus, it does not appear likely that herbivory by reef fishes results in inhibition of gut microflora by the model proposed for penguins (Sieburth 1960, 1961). The absence of any such inhibition is also consistent with previous reports of a diverse gut microflora in various herbivorous reef fishes (Horn 1989).

Although significant decreases occur from the stomach to the gut, ingested DMSP appears to be incompletely degraded; a fraction of ingested DMSP appears to be incorporated by the fish and a fraction excreted. Both DMS emission from fresh feces as well as significant muscle DMSP concentrations were observed in this study. Motohiro's (1962) study of salmon also suggests that DMSP is accumulated. Some uncertainty exists over the relative extent of DMSP and DMS incorporation though, since no distinction between the two was made in the study described here due to analytical ambiguities that might result from the conversion of DMSP to DMS during tissue grinding.

Previous observations suggest that DMSP accumulation is reversible. Ackman et al. (1966) and Iida et al. (1986) demonstrated a rapid accumulation of DMSP in fish tissues; Iida et al. (1986) also showed that DMSP in tissues decreased gradually over about $15 \mathrm{~d}$ when the ingestion of DMSP was restricted. DMSP accumulations were found to be seasonal, brought on by ingestion of DMSP-rich invertebrates (Motohiro 1962). In the reef fish Sparisoma radians, which feeds almost exclusively on relatively DMSP-rich vegetation, any seasonality would probably be linked to changes in the composition and physiology of their plant food. The reversibility of DMSP accumulation and the decomposition of DMSP to DMS in fish guts raise questions about the metabolism of these compounds in fish tissue. DMS is oxidized to DMSO and $\mathrm{DMSO}_{2}$ in mammals (e.g. Williams et al. 1966), and it is reasonable to expect similar processes in fish. There is also the possibility, as has been described in mammals, that DMS is methylated to a trimethylsulfonium salt (Mozier \& Hoffman 1990) that is presumably excreted in urine. The significance of these processes in fishes is unknown.

The muscle DMSP concentrations observed in this study are certainly well above the apparent taste threshold. The human detection limit (smell/taste) for DMS is extremely low, in the range of $10 \mathrm{ppb}$ (Toan et al. 1965) or about $0.16 \mu \mathrm{mol} \mathrm{kg}{ }^{-1}$ in distilled water. Apparently the sensation of DMS shifts from neutral and positive to undesirable with increasing concentration. Concentrations of DMSP in tissues of all specimens were high enough to expect a flavor effect if the DMSP were decomposed to DMS - which happens readily in cooking. Concentrations of DMS in oysters have been described as a positive flavor component (Ronald \& Thomson 1964), whereas DMS has been identified as a flavor problem in cod (Sipos \& Ackman 1964).

The presence of SCFA in the gut contents, particularly the fore- and hind-guts, is indicative of an active anaerobic gut microflora, which may play a role in ACR degradation and perhaps DMSP decomposition as well. Anaerobic microbiota have been previously observed in other herbivorous fishes and are common for non-piscine marine herbivores (e.g. Wolin 1979, Bjorndal 1980, Murray 1981, Rimmer \& Wiebe 1987). An anaerobic microflora could facilitate digestion of complex plant polymers (Anderson 1987), providing the host fish with useful metabolic intermediates, including SCFA, amino acids, vitamins or other required nutrients. However, contrary to the specialized adaptations of other herbivores (e.g. ruminants, herbivorous turtles and insects, manatees), most marine herbivorous fishes have a simple gut architecture and short retention times of a few hours or less (Lobel 1981, Horn 1989) that appears to limit the importance of the gut microbiota. Of course, it should be noted that remarkable prokaryotic symbionts have been observed in the guts of several herbivorous and detritivorous acanthurids (Clements et al. 1989, Clements \& Bullivant 1991) and a unique gut architecture and anaerobic fermentation has been observed in 2 herbivorous kyphosids (Rimmer \& Wiebe 1987). Though concentrations of acetate and propionate found in this study are comparable to those in other herbivores, short gut retention times may preclude a significant nutritional role for SCFA. Unlike terrestrial 
herbivores, many herbivorous reef fishes apparently maximize plant throughput, depending on readily utilizable organics rather than the digestion of more complex structural materials.

In summary, the exposure of fish to DMSP is related to their food preferences. Ingested DMSP, and ACR, one of its degradation products, is consumed significantly in the stomach and foregut of reef herbivores by the fish and/or by bacteria. The fate of DMS, the other end-product, is uncertain; DMSP, DMS or both appear to accumulate in fish muscle and both are apparently excreted, perhaps with ACR as well. The role of ACR in the physiology and microbiology of the digestive system of fishes needs further study, but our data suggest negligible inhibitory effects.

Acknowledgements. We thank the staff of the West Indies Laboratory in St. Croix for their cooperation and support during our study. Funding was provided by NOAA Sea Grant, NASA, NSF, and ONR.

\section{LITERATURE CITED}

Ackman, R. G., Dale, J., Hingley, J. (1966). Deposition of dimethyl- $\beta$-propiothetin in Atlantic cod during feeding experiments. J. Fish. Res. Bd Can. 23: 487-497

Ackman, R. G., Hingley, J., May, A. W. (1967). Dimethyl- $\beta-$ propiothetin and dimethyl sulfide in Labrador cod. J. Fish. Res. Bd Can. 24: 457-461

Anderson, T. A. (1987). Utilization of algal cell fractions by the marine herbivore the luderick, Girella tricuspidata (Quoy and Gaimard). J. Fish. Biol. 31: 221-228

Andreae, M. O. (1990). Ocean-atmosphere interactions in the global biogeochemical sulfur cycle. Mar. Chem. 30: $1-29$

Belviso, S., Kim, S. K., Rassoulzadegan, F., Krajka, B. C. Mihalopoulos, Buat-Menard, P. (1990). Production of dimethylsulfonium propionate (DMSP) and dimethylsulfide (DMS) by a microbial food web. Limnol. Oceanogr. 35: $1810-1821$

Bjorndal, K. A. (1980). Nutrition and grazing behaviour of the green turtle Chelonia mydas. Mar. Biol. 56: 147-154

Cantoni, G. L., Anderson, D. G. (1956). Enzymatic cleavage of dimethylpropiothetin in Polysiphonia lanosa. J. biol. Chem. 222: 171-177

Challenger, F. (1959). Aspects of the organic chemistry of sulphur. Academic Press, New York

Challenger, F., Simpson, M. I. (1948). Studies of biological methylation. Part XII. A precursor of the dimethyl sulfide evolved by Polysiphonia fastigiata. Dimethyl- $\beta$-carboxyethyl sulphonium hydroxide and its salts. J. Chem. Soc. 1948: 1591-1597

Charlson, R. J., Lovelock, J. E., Andreae, M. O., Warren, S. G. (1987). Oceanic phytoplankton, atmospheric sulfur, cloud albedo and climate: a geophysiological feedback. Nature 326: $655-661$

Clavijo, I. E. (1974). A contribution to the feeding habits of three species of Acanthurids (Pisces) from the West Indies. M.Sc. thesis, Florida Atlantic Univ., Boca Raton

Clements, K. D., Bullivant, S. (1991). An unusual symbiont from the gut of surgeonfishes may be the largest known prokaryote. J. Bacteriol. 173: 5359-5362
Clements, K. D., Sutton, D. C., Choat, J. H. (1989). Occurrence and characteristics of unusual protistan symbionts from surgeonfishes (Acanthuridae) of the Great Barrier Reef, Australia. Mar. Biol. 102: 403-412

Dacey, J. W. H., Blough, N. V. (1987). Hydroxide decomposition of dimethylsulfoniopropionate to form dimethylsulfide. Geophys. Res. Lett. 14: 1246-1249

Dacey, J. W. H., Wakeham, S. G. (1986). Oceanic dimethylsulfide: production during zooplankton grazing on phytoplankton. Science 233: 1314-1316

Dacey, J. W. H., Wakeham, S. G., King, G. M. (1987). Factors controlling emission of dimethylsulfide from salt marshes. Nature 330: 643-645

Dickson, D. M. J., Jones, R. G. W., Davenport, J. (1980). Steady state osmotic adaptation in Ulva lactuca. Planta 150: $158-165$

Dickson, D. M. J., Davenport, J., Jones, R. G. W. (1982). Osmotic adaptation in Ulva lactuca under fluctuating salinity regimes. Planta 155: 405-415

Duarte, S. A., Acero, A. (1988). Hábitos alimentarios de los peces del género Acanthurus (Perciformes: Acanthuridae) en la región de Santa Maria (Caribe Colombiano). Rev. Biol. Trop. 36(2B): 399-405

Emery, A. R. (1973). Comparative ecology and functional osteology of fourteen species of damselfishes (Pisces: Pomacentridae) at Alligator Reef, Florida Keys. Bull. mar. Sci. Gulf Caribb. 23: 649-770

Horn, M. H. (1989). Biology of marine herbivorous fishes. Oceanogr. mar. Biol. A. Rev. 27: 167-272

Iida, H., Nakazoe, J., Saito, H., Tokunaga, T. (1986). Effect of diet on dimethyl- $\beta$-propiothetin content in fish. Bull. Jap. Soc. scient. Fish. 52: 2155-2161

Iida, H., Tokunaga, T. (1986). Dimethyl sulfide and dimethyl$\beta$-propiothetin in shellfish. Bull. Jap. Soc. scient. Fish. 52: $557-563$

Kadota, H., Ishida, Y. (1968). Effects of salts on enzymatical production of dimethyl sulfide from Gyrodinium cohnii. Bull. Jap. Soc. scient. Fish. 34:512-518

Keller, M. D., Bellows, W. K., Guillard, R. L. (1989). Dimethyl sulfide production in marine phytoplankton. In: Saltzman, E. S., Cooper, W. J. (eds.) Biogenic sulfur in the environment. ACS Symposium series 393, Washington, DC, p. $167-182$

Kiene, R. P. (1990). Dimethylsulfide production from dimethylsulfoniopropionate (DMSP) in coastal seawater and bacterial cultures. Appl. environ. Microbiol. 56: 3292-3297

Larher, F., Hamelin, J. (1979). L'acide dimethylsulfonium-5 pentanoique de Diplotaxis tenuifolia. Phytochem. 18: 1396-1397

Larher, F., Hamelin, J., Stewart, G. R. (1977). L'acide dimethyl sulfonium-3 propanoique de Spartina anglica. Phytochem. 16: $2019-2020$

Leck, C., Larsson, U., Bagander, L. E., Johansson, S., Hajdu, S. (1990). Dimethyl sulfide in the Baltic Sea: annual variability in relation to biological activity. J. geophys. Res. 95: 3353-3363

Lobel, P. S. (1980). Herbivory by damselfishes and their role in coral reef community ecology. Bull. mar. Sci. 30: 273-289

Lobel, P. S. (1981). Trophic biology of herbivorous reef fishes: alimentary $\mathrm{pH}$ and digestive capabilities. J. Fish. Biol. 19: 365-397

Lobel, P. S., Ogden, J. (1981). Foraging by the herbivorous parrotfish, Sparisoma radians. Mar. Biol. 64: 173-183

Mozier, N. M., Hoffman, J. L. (1990). Biosynthesis and urinary excretion of methyl sulfonium derivatives of the sulfur mustard analog, 2-chloroethyl ethyl sulfide, and other 
thioethers. FASEB (Fedn Am. Socs, exp. Biol.) J. 4: 3329-3333

Motohiro, T. (1962). Studies on the petroleum odour in canned chum salmon. Mem. Fac. Fish. Hokkaido Univ. 10: 1-65

Murray, R. M. (1981). The importance of VFA in dugong nutrition. In: Marsh, H. (ed.) The dugong. James Cook Univ., Townsville, p. $166-168$

Randall, J. E. (1967). Food habits of reef fishes of the West Indies. Stud. Trop. Oceanogr. 5: 665-847

Reed, R. H. (1983). Measurement and osmotic significance of $\beta$-dimethylsulphoniopropionate in marine macroalgae. Mar. Biol. Lett. 4: 173-181

Rimmer, D. W., Wiebe, W. J. (1987). Fermentative microbial digestion in herbivorous fishes. J. Fish. Biol. 31: 229-236

Ronald, A. P., Thomson, W. A. B. (1964). The volatile sulphur compounds of oysters. J. Fish. Res. Bd Can. 21: 1481-1487

Shaw, G. E. (1983). Bio-controlled thermostasis involving the sulfur cycle. Clim. Change 5: 297-303

Shiomi, K., Noguchi, A., Yamanaka, H., Kikuchi, T., Iida, H. (1982). Volatile sulfur compounds responsible for an offensive odor of the flat-head, Calliurichthys doryssus. Comp. Biochem. Physiol. 71B: 29-31

Sipos, J. C., Ackman, R. G. (1964). Association of dimethyl sulphide with the 'Blackberry' problem in cod from the Labrador area. J. Fish. Res. Bd Can. 21: 423-425

Sieburth, J. McN. (1959). Gastrointestinal microflora of Antarctic birds. J. Bacteriol. 77: 521-531

Sieburth, J. McN. (1960). Acrylic acid, an 'antibiotic' principle in Phaeocystis blooms in Antarctic waters. Science 132: 676-677

Sieburth, J. McN. (1961). Antibiotic properties of acrylic acid, a factor in the gastrointestinal antibiosis of polar marine animals. J. Bacteriol. 82: 72-79

Stefels, J., van Boekel, W. H. M. (1993). Production of DMS from dissolved DMSP in axenic cultures of the marine

This article was presented by D. A. Caron (Senior Editorial Advisor), Woods Hole, Massachusetts, USA phytoplankton species Phaeocystis sp. Mar. Ecol. Prog. Ser. 97: 11-18

Targett, N. M., Targett, T. E., Vrolijk, N. H., Ogden, J. G. (1986). Effect of macrophyte secondary metabolites on feeding preferences of the herbivorous parrotfish Sparisoma radians. Mar. Biol. 92: 141-148

Toan, T. T., Bassette, R., Claydon., T. J. (1965). Methyl sulfide production by Aerobacter aerogenes in milk. J. Dairy Sci. 48: 1174

van Diggelen, J., Rozema, J., Dickson, D. M. J., Broekman, R. (1986). $\beta$-Dimethylsulphoniopropionate, proline, and quaternary ammonium compounds in Spartina anglica in relation to sodium chloride, nitrogen, and sulphur. New Phytol. 103: 573-586

Vairavamurthy, A., Andreae, M. O., Iverson, R. L. (1985). Biosynthesis of dimethylsulfide and dimethylsulfoniopropionate by Hymenomonas carterae in relation to sulfur source and salinity variations. Limnol. Oceanogr. 30: 59-70

Wakeham, S. G., Dacey, J. W. H. (1989). Biogeochemical cycling of dimethyl sulfide in marine environments. In: Saltzman, E. S., Cooper, W. J. (eds.) Biogenic sulfur in the environment. ACS Symposium series 393, Washington, DC, p. $152-166$

White, R. H. (1982). Analysis of dimethylsulfonium compounds in marine algae. J. mar. Res. 40:529-535

Williams, K. I. H., Burstein, S. H., Layne, D. S. (1966). Dimethyl sulfone: isolation from cows' milk. Proc. Soc. exp. Biol. Med. 122: 865-866

Wolin, M. J. (1979). The rumen fermentation: a model for microbial interactions in anaerobic ecosystems. Adv. microb. Ecol. 3: 49-77

Wyn Jones, R. G., Storey, R. (1981). Betaines. In: Paleg, L. G., Aspinall, D. (eds.) The physiology and biochemistry of drought resistant plants. Academic Press, Sydney, p. $171-204$

Manuscript first received: October 12, 1993

Revised version accepted: March 29, 1994 